\title{
UPAYA PENINGKATAN KETERAMPILAN LOMPAT JAUH GAYA JONGKOK DENGAN MODEL BERMAIN BOX TO BOX
}

\author{
Argo Dwiyu Laksono \\ SD N 2 Sokaraja Kulon, Purwokerto, Indonesia \\ Email: argidwiyulaksono@ rocketmail.com
}

\begin{abstract}
Students' skill in doing long jump of squat style was still low, thus it needed to improve. This research that aimed to improve students' skill of long jump of squat style through Box To Box game model for the fifth graders SD N 2 Sokaraja Kulon academic year pf 2014/2015 that contained 37 students; 16 females and 21 males. The techniques of data collection used observation, documentation, and perfomances assessment. The results showed that through Box To Box game model was able to improve students' skill of long jump of squat style from pre-cycle to cycle I and cycle II. The students' skill of long jump of squat style in cycle I showed that the mastery percentage $46 \%$ or 17 students. In cycle II mproved become $89 \%$ or 33 students. The data above showed that there was improvement of students' long jump skill of squat style which was $43 \%$. The research conclussion was the implementation of Box To Box game model was able to improve students' skill of long jump of squat style for the fifth graders SD N 2 Sokaraja Kulon.
\end{abstract}

Keywords: skill, long jump of squat style, Box To Box

Abstrak. Kemampuan siswa dalam melakukan lompat jauh gaya jongkok masih rendah, sehingga perlu ditingkatkan. Penelitian ini merupakan Penelitian Tindakan Kelas yang bertujuan untuk meningkatkan keterampilan lompat jauh gaya jongkok dengan model bermain box to box di kelas $\mathrm{V}$ SD Negeri 2 Sokaraja Kulon. Subjek pada penelitian ini adalah siswa kelas VA SD N 2 Sokaraja Kulon tahun ajaran 2014/2015 yang berjumlah 37 siswa terdiri dari 16 siswa putri dan 21 siswa putra. Teknik pengumpulan data yang digunakan dalam penelitian ini yaitu observasi, dokumentasi, dan penilaian unjuk kerja. Hasil penelitian menunjukkan bahwa melalui model bermain box to box dapat meningkatkan keterampilan lompat jauh gaya jongkok dari pra siklus ke siklus I dan dari siklus I ke siklus II. Keterampilan lompat jauh gaya jongkok siswa pada siklus I menunjukan kategori ketuntasan adalah $46 \%$ atau 17 siswa. Pada siklus II terjadi peningkatan presentase keterampilan lompat jauh gaya jongkok yaitu $89 \%$ atau 33 siswa. Data di atas menunjukkan terdapat peningkatan keterampilan lompat jauh gaya jongkok sebesar $43 \%$. Simpulan penelitian ini yaitu penerapan model bermain box to box dapat meningkatkan keterampilan lompat jauh gaya jongkok pada siswa kelas V SD N 2 Sokaraja Kulon.

Kata kunci : Keterampilan, lompat jauh gaya jongkok dan model bermain box to box.

\section{LATAR BELAKANG}

Pendidikan di Sekolah Dasar (SD) dalam proses pembelajaran harus sesuai dengan karakteristik siswa, salah satunya anak masih senang bermain sehingga guru harus bisa membawa suasana pembelajaran menjadi menyenangkan bagi peserta didik. Salah satu pembelajaran yang dilakukan di SD adalah mata pelajaran Pendidikan Jasmani Olahraga dan Kesehatan (Penjasorkes).
Pendidikan jasmani olahraga dan kesehatan disingkat penjasorkes. Penjasorkes merupakan istilah yang terdapat di dalam kurikulum 2006 yaitu Kurikulum Tingkat Satuan Pendidikan (KTSP). Istilah ini pada tahun 1983 oleh MPR dinamakan pendidikan jasmani dan olahraga. Kemudian pada tahun 1987 berdasarkan surat keputusan Mendikbud 413/U/1987 istilah Pendidikan Olahraga dan Kesehatan diubah menjadi pendidikan jasmani. 
Pendidikan Jasmani adalah suatu proses pembelajaran melalui aktivitas jasmani yang didesain untuk meningkatkan kebugaran jasmani, mengembangkan keterampilan motorik, pengetahuan dan perilaku hidup sehat dan aktif, sikap sportif, dan kecerdasan emosi. Pendidikan jasmani diharapkan dapat melengkapi proses pembelajaran di sekolah dasar yang mampu membuat tubuh siswa menjadi sehat dan bugar(Samsudin, 2008:2).

Pendidikan jasmani dan olahraga dapat diartikan suatu kegiatan mendidik anak dengan proses pendidikan melalui aktivitas jasmani dan olahraga. Perbedaan penjasorkes dengan mata pelajaran lainnya adalah alat yang digunakan adalah gerak insani, manusia yang bergerak secara sadar. Gerak itu dirancang secara sadar oleh gurunya dan diberikan dalam situasi yang tepat, agar dapat merangsang pertumbuhan dan perkembangan anak $\operatorname{didik(Paturusi,~2012:5).~}$

Berdasarkan hasil wawancara dengan beberapa siswa kelas $\mathrm{V}$ mereka mengatakan bahwa mata pelajaran penjasorkes khususnya materi lompat jauh gaya jongkok masih banyak siswa yang kurang menguasai, dari segi materi maupun praktiknya. Terbukti dengan prestasi lompat jauh gaya jongkok siswa masih banyak yang belum memenuhi Kriteria Ketuntasan Minimal (KKM). Hasil wawancara pada guru Penjasorkes diperoleh rendahnya prestasi belajar disebabkan antusias siswa dalam belajar penjasorkes masih rendah, kurangnya permainan yang menarik untuk merangsang lompatan siswa.

Kemampuan lompat jauh gaya jongkok ini ternyata tidak mudah bagi siswa Sekolah Dasar (SD). Hal ini disebabkan karena beberapa faktor, antara lain kurangnya pemanasan sebelum melakukan lompatan, kurangnya latihanlatihan sebelum melakukan lompatan dengan permainan yang menarik, dan kurangnya pengetahuan siswa dalam melakukan lompatan yang benar. Dalam kasus di lapangan umumnya guru tidak memberikan latihan-latihan kepada siswa untuk memacu kemampuan lompatan yang bisa menghasilkan hasil tolakan yang jauh. Prestasi siswa dalam lompat jauh masih terlihat kurang, karena masih terdapat beberapa siswa yang kurang jauh dalam melakukan lompatan.

Permainan box to box atau melompat dari kardus yang disusun secara berbanjar lurus, zig-zag, dan melingkar ini dapat digunakan untuk melatih kemampuan lompatan siswa. Permainan ini akan merangsang siswa untuk melompat lebih jauh dan berlomba dengan temannya. Permainan box to box juga bisa menjadi menyenangkan bagi siswa.

Peneliti ingin meningkatkan prestasi lompat jauh gaya jongkok dengan model permainan box to box di kelas V SDN 2 Sokaraja Kulon, peneliti juga ingin melatih salah satu nilai karakter siswa yaitu menghargai prestasi, karena pentingnya nilai menghargai prestasi untuk diajarkan sejak dini. Guru juga memberikan pembelajaran atletik yang menarik bagi siswa SD karena hal tersebut merupakan kewajibannya, namun model pembelajaran yang menarik belum banyak diterapkan di SD.

\section{METODE PENELITIAN}

Penelitian ini merupakan Penelitian Tindakan Kelas (PTK) atau Classroom Action Research yang berfokus pada upaya kondisi nyata dalam satu kelas kearah yang diharapkan. Penelitian ini dilaksanakan di SD Negeri 2 Sokaraja Kulon Kecamatan Sokaraja, Kabupaten Banyumas pada semester II tahun ajaran 2014/2015, karena menurut peneliti prestasi lompat jauh siswa masih tergolong rendah, disamping itu guru juga belum menggunakan model pembelajaran yang menyenangkan untuk melatih gerak dasar lompat jauh gaya jongkok.

Penelitian dilakukan selama bulan April sampai Mei 2015, Tahun Ajaran 2014/2015, siklus 1 dilaksanakan pada tanggal 10 dan 17 April, siklus 2 pada tanggal 1 dan $15 \mathrm{Mei}$, dengan harapan data yang diperoleh dirasa sudah lengkap sesuai 
dengan yang diharapkan. Penelitian tindakan kelas ini sangat tergantung keaktifan siswa, guru serta kolaborator sehingga hasil yang diharapkan setiap siklus pembelajaran dapat meningkat dan tercapai dengan baik.

Peneliti sendiri adalah Mahasiswa PGSD calon Guru SD, Guru Penjasorkes SD Negeri 2 Sokaraja Kulon yaitu Sukesih, S. Pd sebagai kolabolator, dan teman sejawat Yunita Pratiwi sebagai kameramen. Siswa yang menjadi objek penelitian adalah siswa kelas V SD Negeri 2 Sokaraja Kulon dengan jumlah 72 siswa, terdiri kelas VA berjumlah 37 siswa.

Instrumen penelitian menggunakan lembar observasi untuk mengetahui aktivitas guru dan siswa, unjuk kerjauntuk mengetahui kemampuan serangkaian gerakan lompat jauh gaya jongkok, dan tes praktek untuk mengetahui prestasi lompat jauh.Keabsahan data dilakukan dengan teknik triangulasi data dalam pengujian kredibilitas ini diartikan sebagai

pengecekan data dari berbagai sumber dengan berbagai cara, dan berbagai waktu. Selanjutnya untuk menguji kredibilitas data melalui triangulasi teknik dilakukan dengan cara mengecek data dengan sumber yang sama namun dengan teknik yang berbeda. Misalnya, data diperoleh dengan wawancara, lalu dicek dengan observasi, dokumentasi, atau kuesioner. Triangulasi dalam pengujian kredibilitas ini diartikan sebagai pengecekan data dari berbagai sumber dengan berbagai cara, dan berbagai waktu (Sugiyono, 2010:372).

\section{HASIL DAN PEMBAHASAN}

Berdasarkan hasil analisis data dari siklus I dan siklus II, maka hasil penelitian tindakan menunjukkan bahwa terjadi peningkatan keterampilan siswa dalam melakukan lompat jauh gaya jongkok. Hal ini dapat dilihat pada tabel 1 yang menggambarkan peningkatan keterampilan dari siklus I ke siklus II.

Tabel 1

Keterampilan siswa dalam melakukan lompat jauh gaya jongkok

\begin{tabular}{|c|c|c|c|}
\hline PRESENTASE LOMPATAN & PRETEST & SIKLUS I & SIKLUS II \\
\hline RATA-RATA & $\mathbf{5 4}$ & $\mathbf{6 4}$ & $\mathbf{7 5}$ \\
\hline PRESENTASE & $\mathbf{1 8 \%}$ & $\mathbf{4 6 \%}$ & $\mathbf{8 9 \%}$ \\
\hline
\end{tabular}

Dari hasil yang telah dicapai siswa pada tes awal, siklus I, dan siklus II, sangat jelas kemajuan yang dicapai. Pada penilaian akhir siklus I perolehan nilai rata-rata kelasya itu 64 belum mencapai tingkat KKM, yaitu 72. Pada akhir siklus II mengalami peningkatan nilai rata-rata kelas secara signifikan yaitu 75. Dengan demikian dapat dikatakan bahwa pembelajaran lompat jauh gaya jongkok dengan permainan box to box berhasil untuk meningkatkan keterampilan siswa.

Permainan box to box dapat meningkatkan keterampilan siswa dalam pembelajaran, karena siswa sebelum melakukan lompat jauh gaya jongkok dirangsang dalam lompatannya dengan permainan ini. Dengan permainan ini siswa berlatih tentang ketepatan, koordinasi, konsentrasi dan keberanian dalam melewati rintangan kardus yang disusun secara berbanjar sampai melingkar. Permainan box to box ini digunakan sebagai media untuk melatih siswa dalam melakukan lompatan dengan tepat. (Sanjaya, Wina 2012: 58).

Pembelajaran lompat jauh gaya jongkok dengan menggunakan model bermain box to box ini membuat siswa lebih tertantang dan serius dalam melakukan pembelajaran, dalam praktiknya ada beberapa siswa yang mash mengalami kesulitan dalam melakukan model permainan ini, dengan adanya arahan dari guru siswa yang mengalami kesulitan akhirnya menjadi bisa. Terjadi peningkatan yang signifikan sebelum menggunakan model bermain dengan sesudah menggunakan model bermain 
dalam pembelajaran lompat jauh gaya jongkok.

Model permainan box to box bisa ini juga dirancang sesuai dengan karakteristik siswa SD yang masih senang bermain dalam pembelajaran, dengan teknik model permainan ini siswa lebih paham tentang lompatan yang benar. Dalam pembelajaran lompat jauh gaya jongkok penentuan kaki dalam melompat merupakan hal yang sangat penting untuk mendapatkan hasil yang maksimal, pembelajaran dengan pemanasan sebelum pembelajaran lompat jah gaya jongkok berlangsung meggunakan model bermain box to box ini sangat menunjang kebutuhan siswa dalam memahami pembelajaran lebih mudah. (Samsudin, 2008: 73).

\section{SIMPULAN DAN SARAN}

Berdasarkan pembahasan dan hasil penelitian maka dapat disimpulkan bahwa model bermain box to box dapat meningkatkan keterampilan lompat jauh gaya jongkok siswa kelas V SD Negeri 2 Sokaraja Kulon.

Berdasarkanhasilpenelitiandansimpul anmakauntukperbaikanpenelitiandimasa yang akandatangadabeberapa saran yang dapatdisampaikanantaralain :

1. Pada proses permaianan box to box, sebaiknya siswa diberikan contoh sebelum melakukan lompatan, sehingga siswa akan mengerti cara yang benar dalam melakukan lompatan.

2. Guru perlu memantau gerakan siswa dalam melakukan setiap variasi-variasi permainan, sehingga siswa akan melakukan gerakan dengan benar.

\section{DAFTAR PUSTAKA}

Jarver, J. (2005). Belajar dan Berlatih Atletik. Bandung: CV. Pionir Jaya

Kaza(2012). Pengaruh Media

Pembelajaran dengan Papan Persegi

Empa tterhadap Hasil Belajar

Lompat Jauh di SDN. Skripsi.

Tangerang: Fakultas Ilmu

keolahragaan Universitas Tangerang

[online] Tersedia di

[http://portalgaruda.org/?ref=browse

$\underline{\text { mod }=\text { viewarticle \&article }=101720]}$

Paturusi, Achmad (2012). Manajemen

Pendidikan Jasmani dan Olahraga.

Jakarta: Rineka cipta

Pratama, YudhaAdy (2011). Pengaruh

Pembelajaran Modifikasi dengan

Media Kardus terhadap Hasil

Belajar Lompat Jauh Gaya Jongkok.

Skripsi. Semarang: Fakultas Ilmu

Keolahragaan Universitas Negeri

Semarang [online] Tersedia di:

[http://ejournal.unesa.ac.id/index.php

/jurnalpendidikanjasmani/article/vie w/2821/baca-artikel]

Samsudin. (2008). Pembelajaran

Pendidikan Jasmani Olahraga dan

Kesehatan SD/MI. Jakarta: Litera

Sugiyono. (2010). Metode Penelitian

Pendidikan (Pendekatan Kuantitatif,

Kualitatif, dan R\&D). Bandung:

Alfabeta

Syah, Muhibbin. (2010). Psikologi

Pendidikan dengan Pendekatan

Baru. Bandung: PT Remaja Rosdakarya Offset 